\title{
Regulatory Role of Nitric Oxide on the Cardiac Na, K-ATPase in Hypertension
}

\author{
J. VLKOVIČOVÁ ${ }^{1}$, V. JAVORKOVÁ ${ }^{1}$, L. MÉZEŠOVÁ ${ }^{1}$, O. PECHÁŇOVÁ ${ }^{2}$, N. VRBJAR ${ }^{1}$ \\ ${ }^{1}$ Institute for Heart Research, Department of Biochemistry, Slovak Academy of Sciences, \\ Bratislava, Slovak Republic; ${ }^{2}$ Institute of Normal and Pathological Physiology, Centre of \\ Excellence for Cardiovascular Research, Slovak Academy of Sciences, Bratislava, Slovak Republic
}

Received January 25, 2008

Accepted March 25, 2008

On-line March 28, 2008

\section{Summary}

The present study was focused on regulatory role of nitric oxide on functional properties of the cardiac $\mathrm{Na}, \mathrm{K}$-ATPase in three various animal models of hypertension: spontaneously hypertensive male rats (SHR) with increased activity of nitric oxide synthase (NOS) by $60 \%$ (Sh1), SHR with decreased activity of NOS by $40 \%$ (Sh2) and rats with hypertension induced by LNAME (40 mg/kg/day) with depressed activity of NOS by $72 \%$ (LN). Studying the utilization of energy substrate we observed higher $\mathrm{Na}, \mathrm{K}$-ATPase activity in the whole concentration range of ATP in Sh1 and decreased activity in Sh2 and LN. Evaluation of kinetic parameters revealed an increase of $\mathrm{V}_{\max }$ value by $37 \%$ in Sh1 and decrease by $30 \%$ in Sh2 and $17 \%$ in LN. The $K_{M}$ value remained unchanged in Sh2 and $L N$, but was lower by $38 \%$ in Sh1 indicating increased affinity of the ATP binding site, as compared to controls. During the activation with $\mathrm{Na}^{+}$we observed increased $V_{\max }$ by $64 \%$ and increased $\mathrm{K}_{\mathrm{Na}}$ by $106 \%$ in Sh1. In Sh2 we found decreased $V_{\max }$ by $40 \%$ and increased $K_{\mathrm{Na}}$ by $38 \%$. In LN, the enzyme showed unchanged $V_{\max }$ with increased $\mathrm{K}_{\mathrm{Na}}$ by $50 \%$. The above data indicate a positive role of increased activity of NOS in improved utilization of ATP as well as enhanced binding of $\mathrm{Na}^{+}$by the cardiac $\mathrm{Na}$, K-ATPase.

\section{Key words}

Sodium pump • Hypertension $\bullet$ Nitric oxide $\bullet$ Heart

\section{Corresponding author}

Norbert Vrbjar. Institute for Heart Research, Department of Biochemistry, Slovak Academy of Sciences, Dúbravská cesta 9, PO Box 104, 84005 Bratislava 45, Slovak Republic. Fax: +421 2 5477 6637. E-mail: usrdnorb@savba.sk

\section{Introduction}

One of the complications accompanying hypertension is the increase of intracellular concentration of sodium ions in the cardiac tissue (Jelicks and Gupta 1994). Intracellular $\mathrm{Na}^{+}$homeostasis is based on a balance between the influx and efflux of $\mathrm{Na}^{+}$. The influx is mediated by various pathways including $\mathrm{Na}^{+}$leakage through different $\mathrm{Na}^{+}$channels, $\mathrm{Na}^{+}-\mathrm{K}^{+}-2 \mathrm{Cl}^{-}$cotransport, $\mathrm{Na}^{+} / \mathrm{H}^{+}$exchanger and $\mathrm{Na}^{+}-\mathrm{HCO}_{3}^{-}$cotransport. It was suggested that in hypertension the enhanced $\mathrm{Na}^{+}$leakage is mainly responsible for increase of the intracellular $\mathrm{Na}^{+}$ concentration (Friedman 1979, Jones 1982, Zicha and Kuneš 1999). For the efflux of excessive $\mathrm{Na}^{+}$ions out from the cells is responsible the $\mathrm{Na}, \mathrm{K}$-ATPase called also as the sodium pump. Na, K-ATPase (EC 3.6.3.9) is an important integral membrane protein that transports three $\mathrm{Na}^{+}$ions out of the cell and two $\mathrm{K}^{+}$ions into the cell using the energy derived from hydrolysis of one molecule of ATP. This enzyme was also hypothesized to be involved in systemic vascular hypertension through its effects on smooth muscle reactivity and myocardial contractility (Herrera et al. 1988). Various recent studies showed that development of functional alterations of the $\mathrm{Na}, \mathrm{K}-\mathrm{ATPase}$ in response to hypertension induced complications in the cardiovascular system is influenced by nitric oxide (NO) (Vrbjar et al. 1999a,b, Vrbjar and Pecháňová 2002, dos Santos et al. 2003, Xu et al. 2003, Zhou et al. 2002). Therefore, in the present study besides estimating the production of nitric oxide (NO) we focused our attention on two main issues concerning the response of the $\mathrm{Na}, \mathrm{K}$-ATPase, i.e. $\mathrm{Na}^{+}$-handling and 
ATP utilization in hypertensive rats with various intensity of NO synthase activities.

\section{Methods}

Three various animal models of hypertension were studied. The first group was represented by spontaneously hypertensive male rats (SHR) at the age of nine months with increased activity of NOS (Sh1). The second group of SHR (16 weeks old) revealed a decreased activity of NOS (Sh2). In the third group (LN), the hypertension was induced by 4 weeks lasting administration of an inhibitor of NO synthase, L-NAME, in the dose of $40 \mathrm{mg} / \mathrm{kg} /$ day during the period from 13 to 16 weeks of age. The effect of hypertension in three above mentioned models was evaluated in percentage change of investigated parameters as compared to respective age-matched control groups. Number of animals was in each group the same $(n=9)$. The rats were placed in plastic cages and housed in a room with controlled temperature $\left(22-24{ }^{\circ} \mathrm{C}\right)$, a 12-h light-dark cycle and were fed with a regular pellet diet. All procedures used in this study were approved by the Veterinary Council of the Slovakia (Decree 289, part 139, July 9th 2003). The systolic blood pressure (SBP) was measured by the non-invasive method of tail cuff plethysmography.

Cardiac sarcolemmal fraction was prepared from hearts by the hypotonic shock - sodidum iodide treatment method (Vrbjar et al. 1984). Protein concentration was determined by the method of Lowry et al. (1951) using bovine serum albumin as a standard.

The kinetics of $\mathrm{Na}, \mathrm{K}$-ATPase was estimated by measuring the splitting of ATP by $50 \mu \mathrm{g}$ of sarcolemmal proteins at $37^{\circ} \mathrm{C}$. The incubation medium consisted of (mmol/l): 100 imidazole ( $\mathrm{pH} 7.4), 4 \mathrm{MgCl}_{2}, 10 \mathrm{KCl}$, $100 \mathrm{NaCl}$. The utilization of substrate was measured in the range of $0.08-4.00 \mathrm{mmol} / 1$ of ATP. The enzyme kinetics for sodium activation was determined by the same approach, but the concentration of $\mathrm{NaCl}$ varied in the range of 2-100 mmol/1 and the amount of ATP was constant (4 mmol/l).

The calcium- and calmodulin-dependent NO synthase activity was determined in crude homogenates of fresh cardiac tissue by measuring the formation of $\mathrm{L}-\left[{ }^{3} \mathrm{H}\right]$ citrulline from L- $\left[{ }^{3} \mathrm{H}\right]$ arginine (Amersham, UK) according to the method of Bredt and Snyder (1990) with a modification as described by Bernátová et al. (1996). NO synthase activity was expressed as picokatal per gram

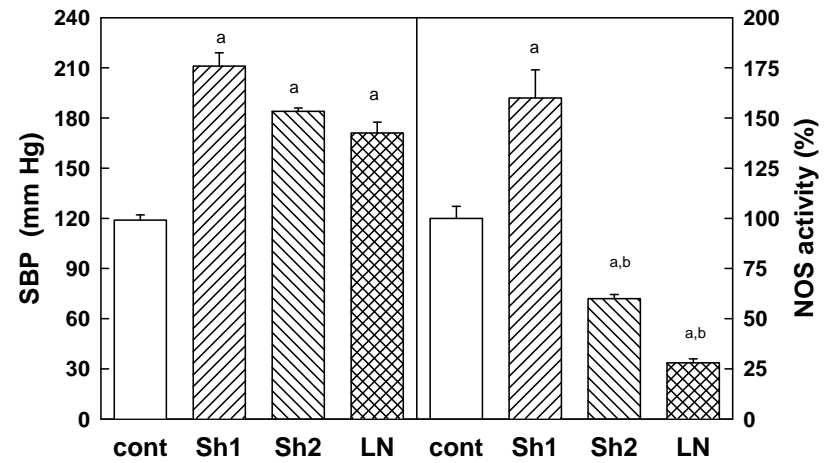

Fig. 1. Systolic blood pressure and cardiac NO synthase activity in control Wistar rats and hypertensive rats. Significant differences $(p<0.05)$ : a: vs. the control group, b: vs. the Sh1 group.

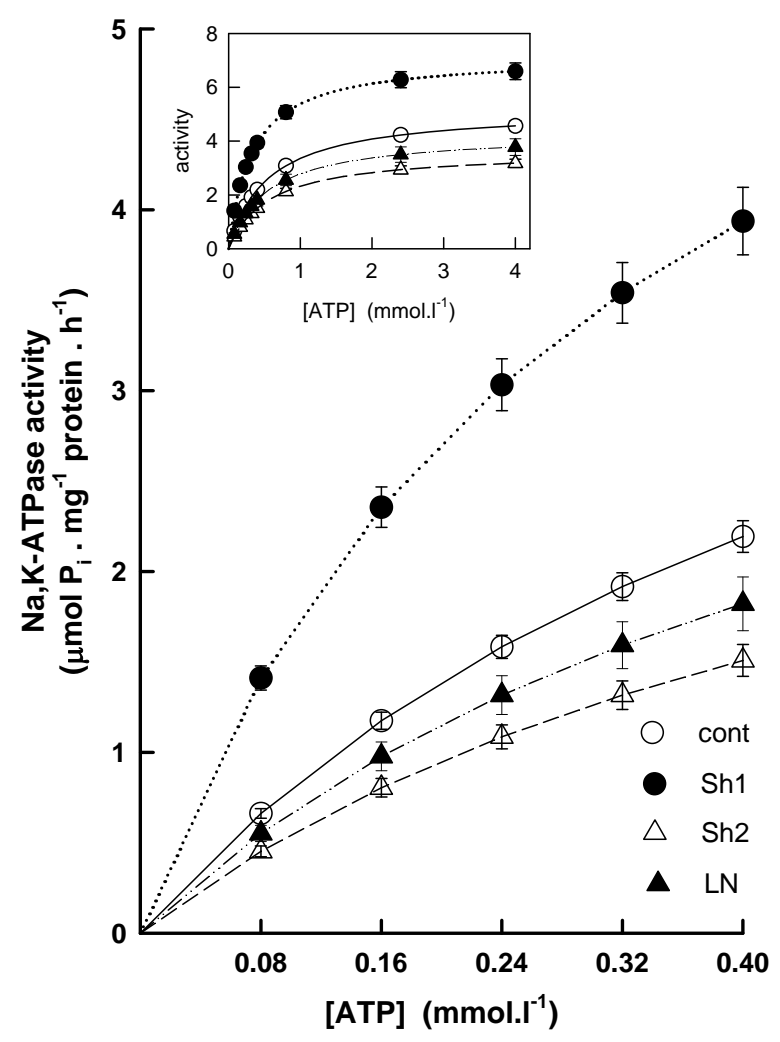

Fig 2. Activation of cardiac $\mathrm{Na}, \mathrm{K}$-ATPase with substrate ATP. Detailed projection of activities in the presence of low concentrations of ATP. Insert: activation of the enzyme in whole concentration range of ATP.

of protein [pkat $\left.\cdot(\mathrm{g} \text { protein })^{-1}\right]$.

The kinetic parameters were evaluated by direct non-linear regression of the obtained data. Results were expressed as a mean \pm SEM. Data were analyzed with the ANOVA and the Bonferroni test to compare individual groups. $\mathrm{P}<0.05$ value was considered significant. 


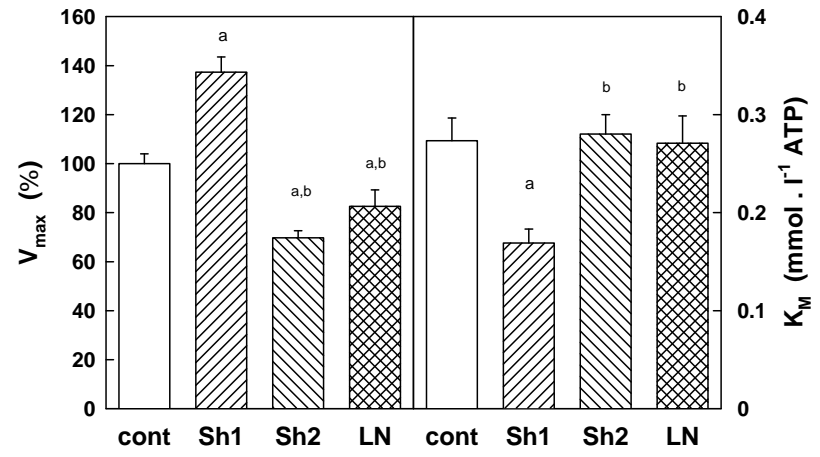

Fig. 3. Kinetic parameters of $\mathrm{Na}, \mathrm{K}$-ATPase activation with substrate ATP in control Wistar rats and hypertensive rats. Significant differences $(p<0.05)$ : a: vs. the control group, b: vs. the Shl group.

\section{Results}

The investigated three hypertensive groups revealed various intensity of NO synthesis in the myocardium in comparison to respective controls. The first SHR group (Sh1) had a significantly higher activity of NO synthase by $60 \%$. The second SHR group (Sh2) was characterized by significant decrease of NO synthase activity by $40 \%$. In the third hypertensive group (LN), the activity of NOS was decreased by $72 \%$ (Fig. 1).

When activating the Na, K-ATPase with increasing concentrations of ATP, we observed significant variations in the three hypertensive groups. In the Sh1 group we found significant increase in the enzyme activity throughout the investigated concentration range of substrate. On the other hand in groups Sh2 and LN with depressed activity of NO synthase we observed a decrease in the Na, K-ATPase activity in the presence of all applied concentrations of substrate ATP (Fig. 2).

Evaluation of the above data resulted in significant increase of the $\mathrm{V}_{\max }$ value for the $\mathrm{Sh} 1$ group by $37 \%$. In the $\mathrm{Sh} 2$ group a significant decrease of $\mathrm{V}_{\max }$ by $30 \%$ and in the LN group by $17 \%$ were observed (Fig. 3). The $K_{M}$ value was significantly lowered in the Sh1 group by $38 \%$. In the groups $\mathrm{Sh} 2$ and $\mathrm{LN}$ the $\mathrm{K}_{\mathrm{M}}$ value remained unchanged, as compared to respective controls (Fig. 3).

Hypertension resulted also in alterations of $\mathrm{Na}^{+}$handling by $\mathrm{Na}$, K-ATPase. In the Sh1 group the enzyme activity was significantly increased especially in the concentration range of $\mathrm{NaCl}$ above $8 \mathrm{mmol} / \mathrm{l}$. In the Sh2 and LN groups the $\mathrm{Na}, \mathrm{K}$-ATPase was lower at all applied $\mathrm{NaCl}$ concentrations (Fig. 4).

Evaluation of the data resulted in significant

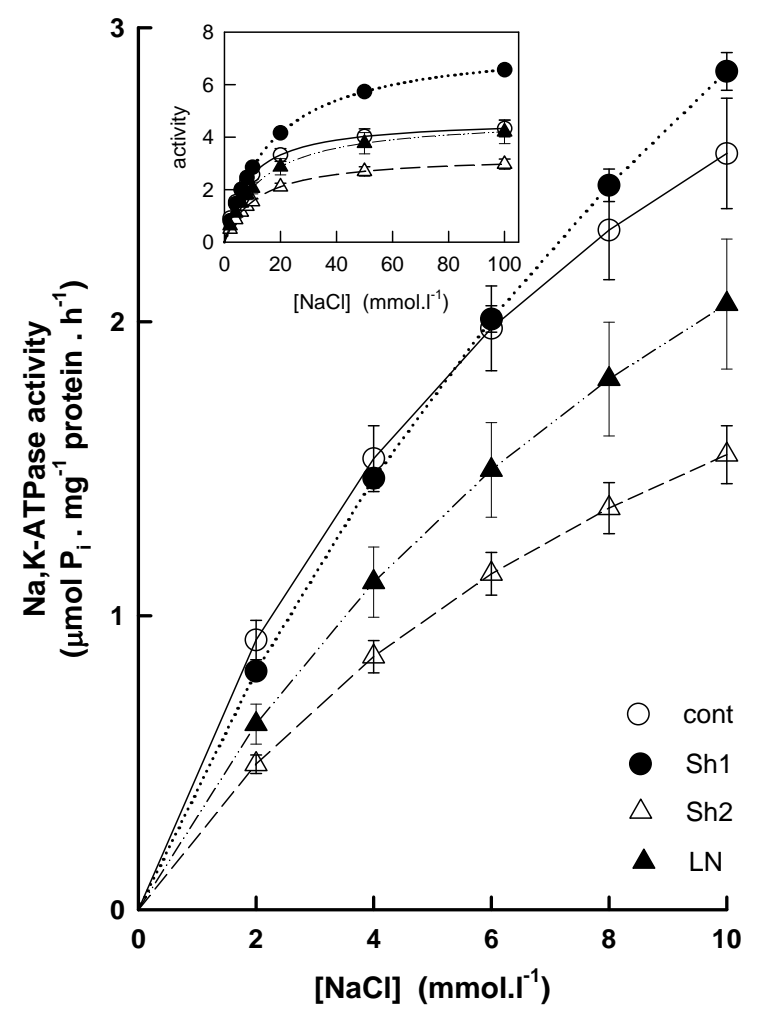

Fig 4. Activation of cardiac $\mathrm{Na}, \mathrm{K}-\mathrm{ATPa} e$ with cofactor $\mathrm{Na}^{+}$. Detailed projection of activities in the presence of low concentrations of $\mathrm{NaCl}$. Insert: activation of the enzyme in the whole concentration range of $\mathrm{NaCl}$.

increase of the $\mathrm{V}_{\max }$ value by $64 \%$ in the $\mathrm{Sh} 1$ group and significant depression of the $\mathrm{V}_{\max }$ in $\mathrm{Sh} 2$ group by $40 \%$. In the $\mathrm{LN}$ group the $\mathrm{V}_{\text {max }}$ did not change as compared to controls. The $\mathrm{K}_{\mathrm{Na}}$ was significantly increased in all three hypertensive groups. The increase represented $106 \%$ in Sh1, $38 \%$ in Sh2 and $59 \%$ in LN group (Fig. 5).

\section{Discussion}

Concerning the activity of NO synthase in SHR inconsistent data were published. The function of $\mathrm{NO}$ synthase was found to be diminished (Malinski et al. 1993), unaltered (Minami et al. 1995) and also augmented in SHR (Nava et al. 1995). In the light of these contradictions and previously documented increased $\left[\mathrm{Na}^{+}\right]_{i}$ in hearts of SHR (Jelicks and Gupta 1994), we focused our attention on the functional properties of the $\mathrm{Na}, \mathrm{K}$-ATPase in hearts from hypertensive rats with different level of NO synthesis in the heart.

Our data suggest that the activity of NO synthase may be a determining factor in regulating the functional properties of the cardiac Na, K-ATPase. In SHR with 


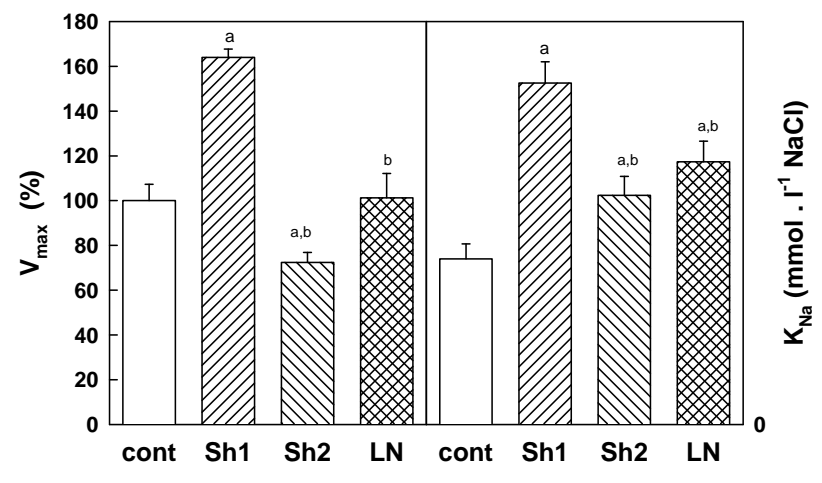

Fig. 5. Kinetic parameters of $\mathrm{Na}, \mathrm{K}$-ATPase activation with cofactor $\mathrm{Na}^{+}$in control Wistar rats and hypertensive rats. Significant differences $(p<0.05)$ : a: vs. the control group, b: vs. the Sh1 group.

increased activity of NO synthase (Sh1) the enzyme showed improved ATP-binding properties as documented by the decreased $\mathrm{K}_{\mathrm{M}}$ value. This finding is supported by observation that pretreatment of hearts with low concentration of NO donor markedly protected the Na, KATPase function against ischemia-induced inactivation (Xu et al. 2003). The importance of NO in the regulation of Na, K-ATPase function is also supported by the fact that in vitro application of NO donors stimulated the vascular sodium pump (Gupta et al. 1994). However, it should be emphasized that the stimulatory effect of NO is limited to the amount of $\mathrm{NO}$ produced by the calcium and calmodulin-dependent constitutive NO synthase (cNOS). If the amount of $\mathrm{NO}$ increases above this limit, the $\mathrm{Na}, \mathrm{K}$ ATPase might be inhibited again, as was demonstrated at very high concentrations of NO generated by the inducible NO synthase (Guzman et al. 1995) or by application of very high concentration of NO donor, sodium nitropruside (Liang and Knox 1999). On the other hand, decreased synthesis of NO (in Sh2 and LN groups) caused an inhibition of the Na, K-ATPase in a place distinct from the ATP-binding site as documented by unaltered values of $\mathrm{K}_{\mathrm{M}}$. Thus, the alterations of $\mathrm{Na}$, KATPase function during hypertension with decreased synthesis of NO probably contribute to pathophysiological changes arising during the disease in the cardiovascular system. Previous data have shown that lowered activity of NOS in rats treated with L-NAME results in hypertension associated with many alterations in cardiovascular system, particularly in hypertrophy of the left ventricle (Bernátová et al. 2002, Pecháňová et al. 2004), in ultrastructural alterations of the heart (Tribulová et al. 2000), in structural changes of the geometry of the aorta, carotid and coronary artery in experimental animal models (Gerová and Kristek 2001), maladaptive gap junction remodeling that consequently promotes development of fatal arrhythmias (Fialová et al. 2008) as well as enhanced triggering of angiogenesis (Okruhlicová et al. 2000) and angiopathy of cardiac capillary system (Okruhlicová et al. 2005).

Concerning the mechanism of the protection of the enzyme molecule by nitric oxide four different hypotheses seem to be plausible.

It was documented that increased amount of $\mathrm{NO}^{\circ}$ protects the $\mathrm{Na}, \mathrm{K}-\mathrm{ATPase}$ activity against exogenous $\cdot \mathrm{OH}$ induced inactivation by scavenging hydroxyl radicals (Zhou et al. 2000), which directly inhibit the $\mathrm{Na}$, K-ATPase by attacking its ATP binding site (Xu et al. 1997).

The second explanation for the observed hypertension-induced inhibition may be the interaction of an inhibitory compound on the enzyme molecule. The role of such a hypothetical inhibitor probably responsible for this process might be ascribed to a digitalis-like substance which was found elevated in SHR causing a decrease of cardiac Na, K-ATPase activity (Chen et al. 1993a,b). It should be mentioned that the digitalis-like substance is freely circulating in blood and is relatively well soluble. Therefore in our experiment, the action of such an inhibitor seems to be limited to its presence in tightly membrane bound form.

The third explanation may include the involvement of increased production of angiotensin II (Ang II) during hypertension with lowered synthesis of $\mathrm{NO}$ as it was indicated by protective effect on the cardiovascular system during NO-deficient hypertension (Pecháňová et al. 1997, Pecháňová and Šimko 2007). The conception of nitric oxide and Ang II participation in regulation of cardiac $\mathrm{Na}, \mathrm{K}-\mathrm{ATPase}$ is supported by protective effect of daidzein (4',7-dihydroxyisoflavone), a soy phytoestrogen, on the ventricular remodeling in rats with myocardial hypertrophy induced by pressure overload. The daidzein-induced protection was accompanied with significant increase of $\mathrm{NO}$ content and activities of cNOS, Na, K-ATPase and Ca-ATPase. Daidzein simultaneously induced a decrease of the AngII content in left ventricle and serum and also iNOS activity (Zhou et al. 2007).

The fourth explanation may regard to influence of endothelin-1 (ET-1) on the function of Na, K-ATPase in conditions of altered NO synthesis. Recently, it has been shown, that NO may inhibit the synthesis and 
hemodynamic effects of ET-1, which in turn may stimulate NO production by means of autocrine interactions with $\mathrm{ET}_{\mathrm{B}}$-receptors (Cardillo et al. 2000). Indeed, increasing circulating and tissue ET-1 immunoreactivity has been observed in patients with coronary artery disease (Lerman et al. 1991) and acute coronary syndromes (Wieczorek et al. 1994). Concerning the influence of ET-1 on the sodium pump activity, controversial data have been published. On one side, it was shown that the vasoconstrictor peptide ET-1 inhibits Na, K-ATPase activity in non-pigmented cilliary epithelial cells (Prasanna et al. 2001) and in the kidney (Hughes et al. 1992, Zeidel et al. 1989). On the other hand, ET-1 stimulates Na, K-ATPase activity in rabbit aorta (Gupta et al. 1991), cerebral capillary endothelium (Kawai et al. 1995) and vascular smooth muscle cells (Redondo et al. 1995) by the PKC-dependent pathway. Thus, the hypothetical involvement of ET-1 in sodium pump regulation is still unclear and for verification of this presumption more detailed studies of the above mentioned pathway in regulation of $\mathrm{Na}, \mathrm{K}$-ATPase pathway will be necessary.

Sodium-binding properties of the Na, K-ATPase were also changed as indicated by increased $\mathrm{K}_{\mathrm{Na}}$ value in all three investigated hypertensive groups. Thus, this change was independent on the activity of NO synthase. However, it should be mentioned that of the $\mathrm{Na}, \mathrm{K}$ ATPase activity in the Sh1 group (with increased activity of NOS) was not lowered at any sodium concentration applied and at concentrations exceeding the $\mathrm{K}_{\mathrm{Na}}$ value the enzyme was additionally stimulated, as compared to controls. So, the decreased sensitivity to $\mathrm{Na}^{+}$suggests that in the Sh1 group the enzyme adapts to altered homeostasis of ions induced by the increased blood pressure and is able to extrude the excessive $\mathrm{Na}^{+}$out from myocardial cells more effectively also at higher $\left[\mathrm{Na}^{+}\right]_{\mathrm{i}}$, while the $\mathrm{Na}$, K-ATPase from control animals is unable to increase additionally its activity. From the fact, that this adaptation of the $\mathrm{Na}^{+}$-binding site was observed in the presence of high activity of NO synthase (Sh1) as well as in the case of lowered activity of NO synthase (Sh2 and LN), it may be hypothesized that this adaptation is probably induced by the increased blood pressure itself, independently on the activity of NO synthase. However, it should be emphasized that in groups with decreased NO synthesis the activity of the Na, K-ATPase was lower in the whole range of $\mathrm{NaCl}$, as compared to Sh1 group. In addition, comparison of our findings and the available data published previously, indicates a progressive increase of the $\mathrm{K}_{\mathrm{Na}}$ value along with the development of hypertension, amounting to $21 \%$ in 7-week-old rats (Godfraind and Noel 1980), $38 \%$ in 16-week-old animals (Vlkovičová et al. 2005), and $106 \%$ in 9-month-old spontaneously hypertensive rats (Vrbjar and Pecháňová 2002). In these alterations regarding the vicinity of the $\mathrm{Na}^{+}$-binding site again the ${ }^{\circ} \mathrm{OH}$ may be involved as it was shown in the case of $\mathrm{Na}, \mathrm{K}$-ATPase subjected to increased concentration of $\mathrm{OH}$ radicals during in vitro conditions (Shao et al. 1995, Lehotský et al. 1999), resulting in decrease of enzyme affinity to sodium in cardiac tissue (Ravingerová et al. 1994). Similar decrease in affinity to sodium was observed also in other pathophysiological situation like chronic hypobaric hypoxia (Rauchová et al. 2006).

We conclude that hypertension was followed by remodeling of the $\mathrm{Na}^{+}$-binding site of the $\mathrm{Na}, \mathrm{K}$-ATPase molecule in the heart as an adaptation to enhanced $\left[\mathrm{Na}^{+}\right]_{\mathrm{i}}$ induced by increased blood pressure, independently on the level of NO synthesis. On the other hand, the elevated activity of NO synthase induced an improvement of the ATP-affinity of the enzyme resulting thus in higher efficiency for utilizing the substrate ATP. In a situation when both effects, the hypertension and elevated activity of NO synthase occurred simultaneously, the influence of elevated activity of NO synthase seems to have a predominant role in regulating the function of cardiac $\mathrm{Na}, \mathrm{K}$-ATPase.

\section{Conflict of Interest}

There is no conflict of interest.

\section{Acknowledgements}

Supported by Slovak Grant Agencies (grants No. VEGA 2/7127/27 and 2/6148/26, APVV 51-059505 and 053807). The authors thank to Mrs. E. Havránková and Mrs. Z. Hradecká for their careful technical assistance.

\section{References}

BERNÁTOVÁ I, PECHÁŇOVÁ O, ŠIMKO F: Captopril prevents NO-deficient hypertension and left ventricular hypertrophy without affecting nitric oxide synthase activity in rats. Physiol Res 45: 311-316, 1996. 
BERNÁTOVÁ I, PECHÁŇOVÁ O, BABÁL P, KYSELÁ S, ŠTVRTINA S, ANDRIANTSITOHAINA R: Wine polyphenols improve cardiovascular remodeling and vascular function in NO-deficient hypertension. Am $J$ Physiol 282: H942-H948, 2002.

BREDT DS, SNYDER SH: Isolation of nitric oxide synthethase, a calmodulin-requiring enzyme. Proc Natl Acad Sci USA 87: 682-685, 1990.

CARDILLO C, KILCOYNE CM, CANNON III RO, PANZA JA: Interactions between nitric oxide and endothelin in the regulation of vascular tone of human resistance vessels in vivo. Hypertension 35: 1237-1241, 2000.

CHEN S, YUAN C, CLOUGH D, HADDY FJ, PAMNANI MB: Role of digitalis-like substance in experimental insulin-dependent diabetes mellitus hypertension. J Cardiovasc Pharmacol 22 (Suppl 2): S20-S21, 1993a.

CHEN S, YUAN C, CLOUGH D, SCHOOLEY J, HADDY FJ, PAMNANI MB: Role of digitalis-like substance in the hypertension of streptozotocin-induced diabetes in reduced renal mass rats. Am J Hypertens 6: 397-406, 1993b.

DOS SANTOS L, XAVIER FE, VASALLO DV, ROSSONI LV: Cycloxygenase pathway is involved in the vascular reactivity and inhibition of the $\mathrm{Na}^{+}, \mathrm{K}^{+}$-ATPase activity in the tail artery from L-NAME-treated rats. Life Sci 74: 613-627, 2003.

FIALOVÁ M, DLUGOŠOVÁ K, OKRUHLICOVÁ L, KRISTEK F, MANOACH M, TRIBULOVÁ N: Adaptation of the heart to hypertension is associated with maladaptive gap junction connexin-43 remodeling. Physiol Res 57: 7-11, 2008.

FRIEDMAN SM: Evidence for enhanced sodium transport in the tail artery of the spontaneously hypertensive rat. Hypertension 1: 572-582, 1979.

GEROVÁ M, KRISTEK F: Efficiency of NO donors in substituting impaired endogenous NO production: a functional and morphological study. Physiol Res 50: 165-173, 2001.

GODFRAIND T, NOEL F: Sodium activation of heart $\left(\mathrm{Na}^{+}, \mathrm{K}^{+}\right)$-ATPase from normotensive and spontaneously hypertensive rats. Arch Int Pharmacodyn Ther 245: 139-144, 1980.

GUPTA S, RUDERMANN NB, CRAGOE EJ, SUSSMAN I: Endothelin stimulates $\mathrm{Na}^{+}-\mathrm{K}^{+}$-ATPase activity by a protein kinase-C pathway in rabbit aorta. Am J Physiol 261: H38-H45, 1991.

GUPTA S, MCARTHUR C, GRADY C, RUDERMAN NB: Stimulation of vascular Na, K-ATPase activity by nitric oxide: a cGMP-independent effect. Am J Physiol 266: H2146-H 2151, 1994.

GUZMAN NJ, FANG MZ, TANG SS, INGELFINGER JR, GARG LG: Autocrine inhibition of $\mathrm{Na}^{+} / \mathrm{K}^{+}$-ATPase by nitric oxide in mouse proximal tubule epithelial cells. J Clin Invest 95: 2083-2088, 1995.

HERRERA VL, CHOBANIAN AV, RUIZ-OPAZO N: Isoform-specific modulation of $\mathrm{Na}^{+}, \mathrm{K}^{+}$-ATPase alpha-subunit gene expression in hypertension. Science 241: 221-223, 1988.

HUGHES AK, CLINE RC, KOHAN DE: Alterations in renal endothelin-1 production in the spontaneously hypertensive rat. Hypertension 20: 666-673, 1992.

JELICKS LA, GUPTA RK: Nuclear magnetic resonance measurement of intracellular sodium in the perfused normotensive and spontaneously hypertensive rat heart. Am J Hypertens 7: 429-435, 1994.

JONES AW: Ionic dysfunction and hypertension. In: Advances in Microcirculation. B ALTURA, E DAVIS, H HARDERS (eds), Karger, Basel, 1982, pp 134-159.

KAWAI N, YAMAMOTO T, YAMAMOTO H, MCCARRON RM, SPATZ M: Endothelin 1 stimulates $\mathrm{Na}^{+}, \mathrm{K}^{+}$-ATPase and $\mathrm{Na}^{+}-\mathrm{K}^{+}-\mathrm{Cl}^{-}$cotransport through $\mathrm{ET}_{\mathrm{A}}$ receptors and protein kinase C-dependent pathway in cerebral capillary endothelium. $J$ Neurochem 65: 1588-1596, 1995.

LEHOTSKÝ J, KAPLÁN P, RAČAY P, MATEJOVIČOVÁ M, DRGOVÁ A, MÉZEŠOVÁ V: Membrane ion transport systems during oxidative stress in rodent brain: protective effect of stobadine and other antioxidants. Life Sci 65: 1951-1958, 1999.

LERMAN A, EDWARDS BS, HALLETT JW, HEUBLEIN DM, SANDBERG SM, BURNETT JC Jr: Circulating and tissue endothelin immunoreactivity in advanced atherosclerosis. $N$ Engl J Med 325: 997-1001, 1991.

LIANG M, KNOX FG: Nitric oxide activates PKC $\alpha$ and inhibits $\mathrm{Na}^{+}-\mathrm{K}^{+}$-ATPase in opossum kidney cells. Am $J$ Physiol 277: F859-F865, 1999.

LOWRY OH, ROSEBROUGH NJ, FARR AL, RANDALL RJ: Protein measurement with the Folin phenol reagent. J Biol Chem 193: 265-275, 1951. 
MALINSKI T, KAPTURCZAK M, DAYHARSH J, BOHR D: Nitric oxide synthase activity in genetic hypertension. Biochem Biophys Res Commun 194: 654-658, 1993.

MINAMI N, IMAI Y, HASHIMOTO J-I, ABE K: Contribution of vascular nitric oxide to basal blood pressure in conscious spontaneously hypertensive and normotensive Wistar Kyoto rats. Clin Sci 89: 177-182, 1995.

NAVA E, NOLL G, LÜSCHER TF: Increased activity of constitutive nitric oxide synthase in cardiac endothelium in spontaneous hypertension. Circulation 91: 2310-2313, 1995.

OKRUHLICOVÁ L, TRIBULOVÁ N, BERNÁTOVÁ I, PECHÁŇOVÁ O: Induction of angiogenesis in nitric oxidedeficient rat heart. Physiol Res 49: 71-76, 2000.

OKRUHLICOVÁ L, TRIBULOVÁ N, WEISMANN P, SOTNÍKOVÁ R: Ultrastructure and histochemistry of rat myocardial capillary endothelial cells in response to diabetes and hypertension. Cell Res 15: 532-538, 2005.

PECHÁŇOVÁ O, ŠIMKO F: The role of nitric oxide in the maintenance of vasoactive balance. Physiol Res $\mathbf{5 6}$ (Suppl 2): S7-S16, 2007.

PECHÁNOVÁ O, BERNÁTOVÁ I, PELOUCH V, ŠIMKO F: Protein remodelling of the heart in NO-deficient hypertension: the effect of captopril. J Mol Cell Cardiol 29: 3365-3374, 1997.

PECHÁŇOVÁ O, BERNÁTOVÁ I, BABÁL P, MARTINEZ MC, KYSELÁ S, ŠTVRTINA S, ANDRIANTSITOHAINA R: Red wine polyphenols prevent cardiovascular alterations in L-NAME-induced hypertension. J Hypertens 22: 1551-1559, 2004.

PRASANNA G, DIBAS A, HULET C, YORIO T: Inhibition of $\mathrm{Na}^{+} / \mathrm{K}^{+}$-ATPase by endothelin-1 in human nonpigmented ciliary epithelial cells. J Pharmacol Exp Ther 296: 966-971, 2001.

RAUCHOVÁ H, VOKURKOVÁ M, DOBEŠOVÁ Z, KUNEŠ J, ZICHA J: Erythrocyte ion transport in rats subjected to acute and chronic hypobaric hypoxia. Physiol Res 55: 711-713, 2006.

RAVINGEROVÁ T, DŽURBA A, VRBJAR N, TRIBULOVÁ N, ZIEGELHÖFFER A, SLEZÁK J: Free oxygen radicals-induced impairment of hearth function: the role of Na,K-ATPase. Pharmacol (Life Sci Adv) 13: 133140, 1994.

REDONDO J, PEIRO C, RODRIGUEZ-MANAS L, SALAICES M, MARIN J, SANCHEZ-FERRER CF: Endothelial stimulation of sodium pump in cultured vascular smooth muscle. Hypertension 26: 177-185, 1995.

SHAO Q, MATSUBARA T, BHATT SK, DHALLA NS: Inhibition of cardiac sarcolemma $\mathrm{Na}^{+}-\mathrm{K}^{+}$-ATPase by oxyradical generating systems. Mol Cell Biochem 147: 139-144, 1995.

TRIBULOVÁ N, OKRUHLICOVÁ L, BERNÁTOVÁ I, PECHÁŇOVÁ O: Chronic impairment of nitric oxide production results in histochemical and subcellular alterations of the rat heart. Physiol Res 49: 77-88, 2000.

VLKOVIČOVÁ J, JAVORKOVÁ V, PECHÁŇOVÁ O, VRBJAR N: Gender difference in functional properties of Na, KATPase in the heart of spontaneously hypertensive rats. Life Sci 76: 971-82, 2005.

VRBJAR N, PECHÁŇOVÁ O: Sodium and ATP affinities of the cardiac (Na, K)-ATPase in relation to nitric oxide synthesis in spontaneously hypertensive rats. Life Sci 71: 1751-1761, 2002.

VRBJAR N, SOOS J, ZIEGELHÖFFER A: Secondary structure of heart sarcolemmal proteins during interaction with metallic cofactors of $\left(\mathrm{Na}^{+}+\mathrm{K}^{+}\right)$-ATPase. Gen Physiol Biophys 3: 317-325, 1984.

VRBJAR N, BERNÁTOVÁ I, PECHÁŇOVÁ O: Changes of sodium and ATP affinities of the cardiac (Na, K)-ATPase during and after nitric oxide deficient hypertension. Mol Cell Biochem 202: 141-147, 1999a.

VRBJAR N, BERNÁTOVÁ I, PECHÁŇOVÁ O: Functional alterations of cardiac (Na, K)-ATPase in L-NAME induced hypertension. Gen Physiol Biophys 18 (Suppl 1): 10-12, $1999 \mathrm{~b}$.

WIECZOREK I, HAYNES WG, WEBB DJ, LUDLAM CA, FOX KA: Raised plasma endothelin in unstable angina and non-Q wave myocardial infarction: relation to cardiovascular outcome. Br Heart J 72: 436-441, 1994.

XU KY, ZWEIER JL, BECKER LC: Oxygen-free radicals directly attack the ATP binding site of the cardiac Na, KATPase. Ann NY Acad Sci 834: 680-683, 1997.

XU KY, KUPPUSAMY SP, WANG JQ, LI H, CUI H, DAWSON TM, HUANG PL, BURNETT AL, KUPPUSAMY P, BECKER LC: Nitric oxide protects cardiac sarcolemmal membrane enzyme function and ion active transport against ischemia-induced inactivation. J Biol Chem 278: 41798-41803, 2003.

ZEIDEL ML, BRADY HR, KONE BC, GULLANS SR, BRENNER BM: Endothelin, a peptide inhibitor of $\mathrm{Na}^{+}-\mathrm{K}^{+}-$ ATPase in intact renaltubular epithelial cells. Am J Physiol 257: C1101- C1107, 1989. 
ZICHA J, KUNEŠ J: Membrane defects and the development of hypertension. In: Development of the Hypertensive Phenotype: Basic and Clinical Studies. Handbook of Hypertension. R MCCARTY, DA BLIZZARD, RL CHEVALIER (eds), Elsevier, Amsterdam, 1999, vol. 19, pp 213-251.

ZHOU L, KUPPUSAMY SP, BECKER LC, LI H, DAWSON TM, BURNETT AL, XU KY: Irreversible injury of nitric oxide synthase associated with cardiac sarcolemma membrane following global ischemia. Circulation 102 (Suppl II): 756, 2000.

ZHOU L, BURNETT AL, HUANG PL, BECKER LC, KUPPUSAMY P, KASS DA, KEVIN DONAHUE J, PROUD D, SHAM JS, DAWSON TM, XU KY: Lack of nitric oxide synthase depresses ion transporting enzyme function in cardiac muscle. Biochem Biophys Res Commun 294: 1030-1035, 2002.

ZHOU L, ZHOU Q, XIONG XQ, LIU JX, HE W: Influence of daidzein on left ventricular remodeling in rats with hypertrophic myocardium induced by pressure overload. Zhongguo Zhong Yao Za Zhi 32: 1449-1452, 2007. 